\title{
LEXICON
}

\section{THE PERSONALITY OF THE SPEAKER OF T.S. ELLIOT'S “PORTRAIT OF A LADY”}

Nia susanti

\section{INTISARI}

Penelitian ini mendiskusikan kepribadian karakter utama yang berfokus pada sikapnya di dalam karya Eliot "Portrait of a Lady". Tujuan dari skripsi ini adalah untuk menemukan kepribadian the speaker yang dilihat dari sikapnya terhadap the lady. Kemudian, pendekatan psikologi digunakan dalam penelitian ini untuk menganalisis kepribadian the speaker. Analisis ini menjelaskan tentang sikap pria terhadap wanita melalui interpretasi data.

Hasil dari penelitian ini menunjukkan bahwa the speaker mempunyai sikap dan kepribadian yang baik terhadap the lady. Dia bersikap tegas therhadap keputusannya untuk tidak memiliki sebuah hubungan percintaan dengan the lady karena terhalang oleh status sosial mereka yang berbeda. Meskipun keduanya mempunyai perasaan yang sama dia menahan perasaannya dan pergi meninggalkan the lady di akhir puisi.

Kata Kunci: Kepribadian, Sikap, Cara Berpikir, Perilaku

\begin{abstract}
This research discusses the personality of the speaker of TS Eliot's "Portrait of a Lady". The objective of this graduating paper is to find the speaker's personality as seen in his attitude toward the lady. The psychological approach is applied in this research to analyze the personality of the speaker. The analysis explains about the speaker's attitude toward the lady by interpreting the data as the primary data.

The result is that he has good attitude and he has a good personality. He is firm with his decision not to have an intimate relationship with the lady which is forbidden by their different social status. Although they have mutual feelings, the speaker restrains his feeling of love toward the lady and leaves her at the end of the poem.
\end{abstract}

Keywords: Personality, Attitude, Way of Thinking, Behavior 


\section{INTRODUCTION}

"Portrait of a Lady" was written by Eliot in 1911. It was first published in 1915 and has the same title with Henry James's novel. This poem is interesting because there are many things that can be learned from the speaker's attitude and his way of thinking related to reality. It is interesting because of the speaker's attitude in responding the lady's during their meeting. This poem actually does not only tell about the lady's depiction about her condition of life and her life. However, it is to discover the speaker's personality. The lady is an important character in this poem because her response toward their relationship which effects the speaker's attitude.

The narrator in this poem is the speaker who is the main character. In this poem, there are conversations between the speaker and the lady during their meeting. However, their conversations are only in the speaker's imagination. The speaker also repeats the lady's speeches to portray the situation of their meeting and conversation.

Eliot uses analogy and romantic atmosphere in his poem which has deeper meaning. Eliot's great works such as "The Love Song for J. Alfred Prufrock", "The Waste Land", "The Hollow Men", and then the one which is analyzed in this paper is "Portrait of a Lady". He creates many works which commonly relates to a situation that has complete relevance for contemporary audiences, and within the framework of modern day society, smart, well-dressed people, the cocktail itself, and the psychiatrist. He nevertheless manages to suggest the most profound and universal of themes-heavenly grace and human salvation. Less profound, perhaps, thought like-wise allegorical (Kunitz 303). "Portrait of a Lady" is interesting because it portrays human life related to the daily activities. It tells about the speaker's personality as seen in his attitude during his relationship with the lady and the society.

This paper is written in order to find out the speaker's personality as seen in his attitude toward the lady in Eliot's "Portrait of a Lady". To achieve the objective the writer focuses the analysis on the speaker's personality which consists of the speaker's way of thinking and the speaker's behavior which builds his attitude. In line with the objectives of this paper, the focus of examination would be on the speaker's attitude as the part of his personality reflected through the conversation between the speaker and the lady during their meetings. This paper analyzes the speaker's personality which focuses on his attitude. Personality which is discussed in this analysis is about the whole character and nature. The personality which analyzes can be seen from his attitude toward the lady, because attitude is a part of personality. Attitude which is known as way of thinking and behaving that people have. Therefore, Psychological approach is applied in this analysis which relates to personality. It uses Freud's theory of personality about Id, Ego, and Superego. According to Freud, literature is an unconscious ambition which does not create in reality and then it is transferred into reality in work fictively. It is possible to examine fictitious character since the authors have made them real by creating characteristic that can be seen through their behaviors, decisions, actions, and reactions in facing problems (Wright 40). According to Abrams, psychological criticism deals with a work of literature primarily as an expression, in fictional form, of the state of mind and structure of personality of the individual author (Abrams 247). It also can be the structure of personality of an individual character that the author builds 
from the reality of life and creates it in to a character in the literary work. This part discusses the background of information about the theory that is used to analyze the main character's personality. The theory that is used in the analysis is psychological theory in relation to personality. Personality is formed by behavior-patterns and it can be influenced by other people and range in society. Personality is about human's character and nature in facing life.

\subsection{The Speaker's Ways of Thinking}

In this poem, the speaker imagines the lady as his object of imagination. He imagines the lady in according to his experience which influences his feeling, belief, and opinion.

Imagination is a picture in the mind which appears because of some experiences or which purely comes from the imagination, then it influences the way of thinking in the process to get a particular idea or opinion (Hornby 744).

The speaker portrays the lady based on his experience and then by imagining the lady, he builds an opinion with his rational thought toward the lady. His imagination makes him to think about the lady, furthermore, from his thinking he remembers the lady and it builds his attitude since they met.

Furthermore, form imagination the speaker builds his way of thinking in facing the reality toward his relationship with the lady. Thinking is a process to have a particular opinion about something or somebody. Then, according to Skinner; Thinking is discovery or invention simply in the sense that verbal environment has evolved in which obscure properties of nature are brought into the control of human behavior (106). Thinking has the dimensions of behavior, not of fancied inner process which finds expression in behavior (117).
It means that thinking is a process of having idea or opinion as part of behavior which comes from human mind where one image, memory, or idea leads to another in a stream of consciousness (117).

The speaker's way of thinking is categorized as his Id because he has desire toward the lady. His desire is that he wants to have romantic relationship with the lady because he has a feeling of love toward her. However, he decides not to make a commitment with her because he considers about the consequence that will happen. According to Freud in his theory:

The organism is equipped with a number of such reflexes for dealing with relatively simple forms of excitation. The primary process involves a somewhat more complicated psychological reaction. It attempts to discharge tension by forming an image of an object that will remove the tension (Hall and Lindzey, "Theories of Personality” 33).

The tension which happens to the speaker is about his feeling of love, but he uses his rationale thought about the impossibility to have an intimate relationship with the lady because the speaker knows that he comes from middle class and the lady comes from high class society. The play role between Id and Ego is that one side, the speaker to have a special relationship with the lady. It can be infer from his visiting to the lady's house, because if he does not interested in the lady and has a feeling of love toward the lady, we would not come to the lady for any reason. However, on the other side the speaker knows that their relationship would not turn into love relationship, furthermore, the speaker only keep his feeling of love toward the lady which represents his Ego. The speaker decides not to have love relationship with the lady, though he has a tension when he visit the lady, then to reduce his tension he is steadfast in his decision to keep his feeling of love. 
In stanza I of part I, it is depicted that the speaker pays visit into the lady's house to have a conversation about their first meeting in December during the winter. In this part the speaker feels uneasy in facing the lady, especially when he knows that the lady prepares herself only to receive him.

You have the scene arrange itself -as it will seem to do-(2)

With "I have saved this afternoon for you" (3) (Eliot 17)

The speaker explains that the lady purposely arranges her room to receive the speaker. Then in line three "I have saved this afternoon for you" which is said by the lady is to emphasize the lady's happiness in having the speaker's visit her at her house. From the way the lady arranges her house with the dim of wax candles in the darkened room which creates romantic situation, it can be inferred that the lady has a feeling toward the speaker and she is interested in him. Another proof that she has a feeling toward the speaker is the fact that she prepares her time for this special meeting only for the speaker.

However, the speaker's perception about the lady's house is that the situation in her house which is dark because it is only lightened by four candles, for him it is not romantic and he is not comfortable with this situation of dark. He thinks that actually he does not need something special from the lady. The speaker assumes that actually the lady does not need to prepare her drawing room as she has arranges it because they are only friends and do not need any romantic situation.

And four wax candles in the darkened room, (4) overhead,

Four rings of light upon the ceiling (Eliot 17)
The speaker describes the lady's house as dark and decorated with the candles to give a dim light in the room of her house. The poem uses the analogy of Shakespeare's famous play entitled "Romeo and Juliet". Here, the speaker describes the lady's drawing room is like Juliet's tomb in a darkened room with the gloomy atmosphere. According to the speaker the drawing room reflects the situation of mourn. The lady is similar with Juliet as the woman who is resting; the lady who feels empty creates her house to receive the speaker and hope for romance with the speaker to make her life happier.

In the reality, the lady's life is empty because she does not have any close friends who can understand her. Therefore, she needs a close or special friend who can understand her and share his or her life experiences. She needs someone to make her lively, for example in the poem the lady shows that she needs a friend with qualities, because she never has a close friend who can make her life more cheerful "To find a friend who has these qualities... Without these friendship-life, what cauchemar!". She says this to the speaker hopefully that he will understand that she needs him. She mentions about the quality of friendship which means that she has friends in society, but they do not have the quality of friendship according to the lady's standard to be a close friend. She needs a friend who can enrich her knowledge about some experience and a close friend who can understand her, also give her some advantages from the relation of friendship or love relationship so her life will not be flat anymore. The speaker thinks that the atmosphere of Juliet's tomb reflects the lady who thinks that her life is flat. This is stated in line 21 stanza II part I, "In a life composed so much, so much of odds and ends" which means that in her life she does not get any pleasure such as having a close friend. 
On the other hand, the description of "An Atmosphere of Juliet's tomb" makes the speaker think that the lady's perception of romance is different from his perception. He does not see the romantic situation in the lady's house as how the lady sees it. It is only set with four candles with the dark room influenced by the condition of winter on December afternoon. He thinks that the situation is gloomy and dark, although the lady sets the candles to create the romantic atmosphere. It shows that both of the speaker and the lady have different perception of romantic atmosphere.

The speaker only keeps his feeling of love toward the lady, because he is aware toward the reality that both of them have different social status. It is stated in Maxwell book "Poetry of T.S. Eliot": The speaker is influenced by European tradition. In European tradition, the society respects the cultural tradition which is related to the social status" (208). He is aware of the fact that he is a middle class man. He does not have the same habit which follows the common rule of high class society such as the habit of having tea in the room, talking about lifestyle of higher class and politics, and the tradition which he knows that the society will allow an intimate relationship between two lovers only when they are in the same social status.

In part III, stanza II line 93 the lady says to the speaker "Perhaps you can write to me" which means that the lady hopes that the speaker will write a letter to her when he is abroad. It is stated in line 89 "So you are going abroad..." However, in reality he never writes a letter to the lady, because he thinks that writing a letter to her will make him remember the lady's love and hope. From this explanation, it can be seen that the speaker has different orientation for their relationship. Here, the Id plays the role in the speaker's hope to have a close relationship with the lady and keep his feeling of love toward her. However, his Ego restrains himself to make any commitment. This is the reason why he does not do anything to make their relationship become an intimate one, though he knows that the lady also has a feeling of love toward him. This line describe the speaker's feeling of love but he thinks that his love is in vain so he thinks that he should keep to his choice not to have a closer relationship with the lady.

Actually, the speaker hopes to have a deeper relationship with the lady which is stated in part I stanza I "Prepared for all the things to be said...". It means that actually the speaker hopes for love and he said that everything which relates to romance is prepared, such as visiting the lady and accompanying her as the proofs that he is interesting with her. However, his way of thinking which is influenced by the reality makes him think that he should leave the lady. It is stated in the continuing line seven part I stanza I “... or left unsaid". It is because he does not want to get any risk from the society; he thinks that they will mock both of them if they make a decision to have a commitment of love relationship. He still has a self-esteem which makes him firm about his decision that is not to make any commitment of love relationship with the lady.

The speaker's he cares for the lady's feeling, but when she hopes for love relationship, he does not do anything (inaction). It represents his Ego;

It is the coherent organization of mental life that shows what on the outside. It is derived from the Id, but shaped and modified by the necessities of the external world" (Horton 340).

The speaker fall in love with the lady and he only keep his feeling of love. He also knows that the lady also loves him. However, he restrains his feeling of love because he thinks that their relationship will not develop. 
The speaker's heavily smile is stated in the line 92 "My smile falls heavily among the bric-à-brac" He knows that the lady has a feeling of love toward him and he thinks that she does not want to let him go because she is comfortable with him as she says that "without this friendship, life what a cauchemar". Furthermore, he smiles but his smile is heavy because he knows the lady's feeling and he also has the same feeling which shows his Id. In the next stanza the lady hopes that the speaker wants to write letter for her. "Perhaps you can write to me". The speaker thinks that if she lets him go easily; she will not ask him to write a letter. The lady thinks that their relationship can be continued although they are in different place.

At the end of the poem, their relationship does not develop to be an intimate relationship. The speaker firmly refuses to make any commitment while the lady hopes to have romantic relationship.

\subsection{The speaker's Behavior}

Behavior is a kind of attitude which comes from activities and habit of a person. Attitude determines personality of a person formed behavior. Skinner in his book "About Behaviorism" says that behavior is a person's action to respond something happening from the mind and feeling.

Behavior expresses feelings, to anticipate what a person will do by guessing or asking him how he feels, and to change the environment in the hope of changing feelings while paying little if any attention to theoretical problems...(Skinner 11).

This part analyzes the speaker's behavior as seen from his actions. His actions toward the lady are his way to respond to the lady and it has a consequence. A behavior is affected by the consequences (Skinner 91).
The speaker's inaction relates to his future relationship with the lady to have an intimate relationship because he does not want any commitment, though, they love each other. In this poem the speaker pays a visit to the lady, though he never shows his aim of his visiting her and having conversation since they meet, however, it can be inferred that he is interested in the lady, because if the speaker is not interested in the lady, then, he will not want to visit her for any reason. Moreover, their relationship happened around ten months since December to October in the following year. In their meeting, they have some conversation such as talking about friendship and he is listening to the lady, for instance, when she is talking about Chopin's music which is admired by the higher class including the lady during the Romantic era. The lady understands and enjoys Chopin as her habit of listening to the music because it is part of her activities of admiring art. However, when the lady talks about Chopin's music, the speaker does not understand because he is not familiar with that.

Frederic Chopin, Polish composer and pianist of the Romantic period, was known for his many piano pieces, of which his "Preludes" is most famous. The music motif in the poem, especially in part one, creates the lady's opinion of intimacy "among friends" (www.britlitwiki.wikispaces.com).

The lady who admires romantic atmosphere says that Chopin's music is intimate. She tries to make the speaker interested in her. The lady's ways to make the speaker interested in her are shown by her actions such as talking about romance among some people and decorating her room with lilacs and candles to create romantic atmosphere. It is in contrast to the speaker's perception which is different from the lady, who thinks that he does not need a romantic atmosphere. The speaker 
does not need any romantic atmosphere in his relationship with the lady. Moreover, the speaker does not see the romantic side from their meeting and their relationship, because he only wants to be the lady's friend. The speaker has different life-style and perception from the lady, he does not think about romantic atmosphere, because he sees everything as what he sees. He sees that the lady's house is dark which only sets with four candles and he thinks that it is not romantic as the lady's intention for romantic atmosphere. He also does not understand when she is talking about romantic music. His life-style and his perception show his attitude that he is a realistic person who always looks something objectively.

Moreover, the speaker's behavior is showed in line 35 to 40 in stanza III of part I. The speaker and the lady leave the lady's drawing room to do new activity after they listens to Chopin's music.

-Let us take the air, in a tobacco trance, Admire the monuments Discuss the late events, Correct our watches by the public clocks. Then sit for half an hour and drink our bocks. (Eliot 17)

These lines show their actions when they leave the lady's drawing room. After that, they go to tobacco trance do other their activities. The setting is in the drawing room. Then, he invites the lady to go to the public places such as going to "public clocks", going to the monument and going to "tobacco trance". The speaker enjoys doing unimportant actions such as "admiring the monument", "discussing about the late events", "correcting watches by the public clock", and then "siting for half an hour and drinking the bocks". These actions show' that their activities are in contrast to the lady's life style such as drinking tea, talking about art, talking about qualities of friendship and doing something to create romantic atmosphere.
The speaker who does not like romantic situation invites the lady to go to public places. The speaker wants the lady to get a new experience which is different from her daily activities. He wants to know the lady's feeling with her new experience, whether she will enjoy her new experience or not, though, in the end of their meeting the speaker asks about the lady's advantage from their activity when they spend their time together, and the lady still hopes the speaker to return. He wants to show to the lady that her life is boring. The speaker's invitation to the lady is proven in line 14 "And so the conversation slips". It means that they have conversation. When the lady explains to the speaker about the rule of attitude in the concert room: "That is rubbed and questioned in the concert room" the lady wants to explain that a conversation can disturb the situation of the concert. However, they have a conversation when they are listening to the music. It shows that the speaker does not pay attention to the lady's explanation, yet the lady thinks that it does not matter because she accepts the speaker's invitation to go outside.

The speaker wants to show the lady that life is not limited only in her house with her routine activities. He wants to show to the lady about many experiences she should get. Her new experience will increase her knowledge and open her mind, furthermore, her way of thinking will not become superficial anymore. His purpose of doing this is to change the lady's way of thinking, in which she only thinks about her empty life, then she does not need to complain about her life which is "composed so much of odds and ends". The speaker's action represents his Ego toward the lady which relates to the reality that their relationship will not turn into love relationship. Then, he wants the lady to be aware of that, furthermore, he hopes the lady can understand him and the 
situation that her needs cannot be fulfilled by the speaker, he only can invite the lady to get new experience hopefully she can learn from her experiences. In the end of the poem, he asks about the advantage of their meeting for the lady, in line 121 part III "Would she not have the advantage after all?" He hopes that the lady can learn from her new experience with the speaker and she can change her mind that life is not always as she wants. He also hopes she can understand that life is wide. Moreover, she can find her happiness as the advantage while she does not get her happiness, though, they do not belong together.

In part II there is evidence that actually the speaker has a crush on the lady but he does not have any confidence to pursue a romantic relationship with the lady. The speaker's action by taking his hat is to respect the lady which is from high class and also the woman he loves.

I take my hat: how can I make a cowardly amends (69)

For what she has said to me? (70) (Eliot 18)

With respect to a person with whom we interact, then, to 'love' is to behave in ways having certain kinds of effects, possibly with accompanying conditions which may be felt (Skinner 49).

His behavior which is shown by respecting the lady also indicates his Superego, because he has a good moral value.

The speaker's behavior is also shown by his action in the part III stanza IV.

And I must borrow every changing shape (109)

To find expression... dance, dance

Like a dancing bear, (111)

Cry like a parrot, chatter like an ape.

The speaker's Superego can be seen by his way of "chatter like an ape". In this action, he criticizes the high class society, because of their behavior who likes to talk about politics and social issue. However, in this context, the speaker wants to criticize their rule of social behavior toward the issue of class status. The speaker knows that the society will forbid the lovers who have different status to make an intimate relationship. Further, he does not want to be mocked by the society. It shows he is aware with the society, and he also respects the society's rule of social status.

Then in section three, she has resigned herself to the fact that he is leaving. The speaker cannot react sincerely to this departure. Instead, he relies on his poise and social programming, which amounts to animal mimicry: "And I must borrow every changing shape/ To find expression...dance, dance,/ Like a dancing bear,/ Cry like a parrot, chatter like an ape" (11.

(www.britlitwiki.wikispaces.com).

In line 113, the speaker says "Let us take the air, in a tobacco trance". In this context, the speaker does the things he wants as his lifestyle. By going to the tobacco trance means that the speaker wants to change his activity and he wants to get his freedom from the pressure because the lady asks him to write a letter to her, because she does not want the speaker to leave her. The lady thinks that if the speaker wants to write a letter, their relationship will still continue. And then he says "Let's us take the air" means that the speaker does not feel comfortable toward their conversation in the end of their meeting, because the lady demands the speaker to do something for her, but the speaker does not want to take any responsibility toward their relationship. His action shows that he needs a place to take the air and to make him refreshed.

Actually, the lady wants to spend her life to wait for the speaker and gives her life to the speaker. Then, when she says "her journey's end" to complete her speech about giving sympathy, she hopes that before her life ends, the speaker will understand that she needs the speaker to make her life happier. 
According to the "Dictionary of Current Idiomatic English Vol.2" that Journey's end means: a goal or conclusion of period in or process of, life or work- and often. Death itself: the end of the road (Cowie 326).

It is the proof that the speaker knows about the lady's intension for special relationship and her indirectly demands for an attention from her speech which makes him uncomfortable. It is because the speaker does not want to make a commitment to the lady, because he does not have any courage which is also proven in the next line:

I keep my countenance, (77)

I remain self-possessed (78) (Eliot 18)

The speaker's behavior in this action shows that he keeps calm toward his relationship with the lady as a friend. Actually, he has a feeling of love toward the lady but he is steadfast with his Ego that he does not want to be more than friends.

In the end of the story their relationship fails. They do not have an intimate relationship because the speaker is still in "self-possession".

The October night comes down; returning as before (84)

Except for a slight sensation of being ill at ease

I mount the stairs and turn the handle of the door

And feel as I had mounted on my hands and knees. (87) (Eliot 20)

In October of the fall Season, the speaker comes to the lady's house as the meeting before. It is the last meeting before the speaker leaves the lady. This is stated in the lady's line "So you are going abroad; and when do you return?", the lady asks the speaker when he will be back. This means that the lady hopes the speaker will come back to the lady or write letters to her "Perhaps you can write to me". But the speaker will leave the lady as soon as possible because he does not want to make any commitment. The speaker's decision of leaving the lady to go abroad and then lets his feeling of love toward the lady without further relationship shows his attitude that he is firm.

He visits the lady where she is sitting in her drawing room waiting for him, and then he said: "I mount the stair and turn the handle of the door". The speaker is uncertain to open the door, because he should come to the lady and say good bye to her.

He is weak when he visits the lady for the last time "And feel as if I had mounted on my hands and knees". He feels as if he crawls, it shows that he is in a condition that he is not as strong as the first time he meets the lady. He is tired because the lady hopes to have an intimate relationship with him, while he knows that it is impossible. She also asks him to write a letter, yet he does not want to write a letter to her. It is because he does not want to make the lady wait for the speaker and it will be difficult to forget each other.

\section{CONCLUSION}

The speaker as the main character in the poem "Portrait of a Lady" by T.S Eliot has a realistic attitude toward the lady as the second main character. However, during their meetings since December to October in the following year the speaker is inaction. He is inaction toward his future relationship with the lady because of his different social status with the lady.

In this poem the speaker has an attitude that he always thinks about the reality he faces. It is shown by the speaker's way of thinking toward the reality that the lady and the speaker cannot be together. He also uses his logical thought during his relationship with the lady.

Moreover, the speaker's personality is shown by his attitude that he cares for the lady. It is shown by his memories and imaginations about her as part of his life. 
He imagines and remembers the lady because she makes him think about her. It indicates his Id as the part of his personality that actually he is interested in the lady and he cares for her. Furthermore, he wants to be close to her, and then he is only remembering and imagining her.

On the other hand, the speaker is a realistic person. He asks the lady to think about the real life which is not limited only in her surroundings. He also makes the lady get new experiences to widen her knowledge. His actions are to make the lady think about the reality that their relationship cannot develop into love relationship because they have different social status. His attitude toward the lady indicates his Ego which is related to the reality. That is why the speaker leaves the lady in the end of the poem. He thinks according to European tradition, that a commitment of love relationship between two lovers who have different social status will bring unpleasant consequences, for instance they can be mocked by the society.

The speaker also respects the lady who has a higher social status. He obeys the society's rule which influences his social life. It shows his good attitude by respecting the lady, though he criticizes the society's rule related to social status. He knows that he is part of the society although he comes from the middle class. He has a good attitude toward the lady which is proven by his actions of responding to the lady when they have conversations in their meetings. His attitude indicates his Superego which is shown by his way of thinking toward the consequences that can happen. He always thinks carefully and he always opens his mind. The speaker also has a firm attitude toward the lady. He is firm to make a decision that they will not have any love relationship.

\section{BIBLIOGRAPHY}

Abrams, M.H. A Glossary of Literary terms $\left(7^{\text {th }}\right.$ ed.). USA: Heinle \& Heinle, a Division of Thompson Learning, Inc, 1999. Print.

A.D. Cowie, R. Mackin, and I.R. McCaig (Editors). Dictionary of Current Idiomatic English Vol.2. London: Oxford University Press, 1983. Print.

Eliot, T.S.. Selected Poems. London: Faber \& Faber Ltd, 1958. Print.

Maxwell, D.E.X. The Poetry of T.S. Eliot. London: Routledge \& Kegan, 1960. Print.

Hall, Calvin S \& Gardner Lindzey. Theories of Personality. New York: John Willey \& Sons, 1957. Print.

Hornby, A.S. Oxford Advanced Learner's Dictionary of Current English. $7^{\text {th }} \mathrm{ed}$. New York: Oxford University Press, 2006. Print.

Skinner, B.F.. About Behaviorism. New York: Alfred A Knopf, 1974. Print.

Stanley J. Kunitz (Editor). A Biographical Dictionary of Modern Literature. New York: The H. W. Wilson Company, 1955. Print.

Wright, Elizabeth. Modern Psychoanalytic Criticism: Modern Literary Theory: A Comparative Introduction. $\left(2^{\text {nd }} e d\right)$. London: B.T. Batsford Ltd, 1991. Print.

"Notes of T.S. Eliot's "Portrait of a Lady.". N.p. n.d. Web.

http://britlitwiki.wikispaces.com/Portrait+o f+a+Lady--Notes (30 November 2013; 3.40 PM). 